\title{
CrimRxiv
}

\section{Modernizing Crime}

Statistics: Report 1:

Defining and Classifying

Crime

\section{National Research Council}

Published on: May 16, 2016

DOI: $10.21428 / \mathrm{cb} 6 a b 371.75577 \mathrm{~d} 79$

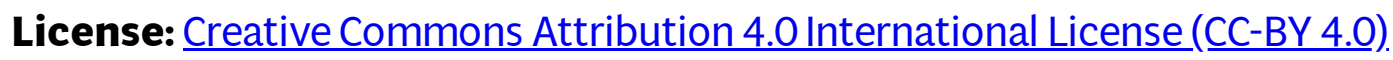


